Шалацька Г. М.

канд. філол. наук, старший викладач ДВНЗ «Криворізький національний університет»

\title{
ЖІНОЧИЙ ОБРАЗ У СИСТЕМІ ДУХОВНИХ ЦІННОСТЕЙ ДРАМАТУРГІЇ М. КОСТОМАРОВА
}

У статті розглянуто жіночі образи трагедій М. Костомарова «Сава Чалий» та «Переяславська ніч» в системі духовних иінностей. Основна увага приділена образам Катерини та Марини як втіленню народного ідеалу жінки. Вони виступають носіями морально-етичних, естетичних, гуманістичних, громадських, суспільних, національних та синкретичних працінностей.

Ключові слова: образ, ідеал, система духовних изіностей, духовність, ментальність.

В статье рассмотрены женские образы трагедий Н. Костомарова «Сава Чальй» $и$ «Переяславская ночь» в системе духовных иенностей. Основное внимание уделено образам Катерины и Марины как воплощеению народного идеала женщины. Они выступают носителями морально-этических, эстетических, гуманистических, гражданских, общественных, наџиональных и синкретических праченностей.

Ключевые слова: образ, идеал, система духовных иченностей, духовность, ментальность.

The article highlights women's characters in the M. Kostomarov's tragedies "Sava Chaly» and «Pereyaslavska night» in terms of system of moral values. The point of specific literary analysis 
has been the character of Katerine and Marine as the embodiment of an ideal woman. The yact as carriers incamates moral, ethic, esthetic, humane, civic, social, national and syncretic Pra values.

Key words: character, ideal, the system of moral values, morality, mentality.

Середина XIX століття - доба активного становлення нових принципів художнього мислення, формування морально-етичних ідеалів, покликаних оздоровити суспільство, спрямувати суспільну свідомість у русло гуманістичних та демократичних цінностей, що грунтуються на національній духовній основі. Утілені в художніх образах «духовні сутності виступають, на думку А. Лісовського, як носї цүіннісного ставлення до явищ життя» [Лісовський 2005: 14]. Жіночі образи, на переконання С. Сфремова, дозволяють найкраще пізнати національний дух [Сфремов 1995: 334]. Зосередження дослідницької уваги на жіночому образі в системі духовних цінностей дозволить визначити художню концепцію національної героїні, окреслити морально-етичні та світоглядні основи письменника. Драматургія М. Костомарова займає особливе місце в українській драматургії першої половини XIX століття. Вона, як i уся творчість письменника, піддавалась забороні, замовчуванню та забуттю. У вітчизняному літературознавстві дослідники висловлювали досить суперечливі судження щодо його драматургії, тому є потреба у грунтовному іï вивченні.

Як зазначав В. Івашків, «драматургічна творчість Костомарова $\epsilon$ важливим етапом у загальному прочесі історико-літературного розвитку всієї украӥнської драматургії $і$ романтичної в тому числі. Його твори "Сава Чалий» i «Переяславська ніч» - перші зразки украӥнських романтичних історичних mрагедій» [Івашків1990: 61]. М. Костомаров вважав, що важливим завданням тогочасної української літератури $є$ створення яскравих національних характерів. Саме такими виразними носіями української ментальності постають Катерина («Сава Чалий») та Марина («Переяславська ніч»). На думку М. Яценка, Марина є «уособленням безкомпромісного національного духу» [Яценко 2005: 345].

Проблема обов’язку перед народом гостро порушувалася у драматургії М. Костомарова. Вона постає нерозривно 3 особистою трагедією головного 
героя та його дружини у драмі «Сава Чалий», у якій виведено позитивний образ дівчини Катерини, яка хоч i не постає головним персонажем твору, але акумулює у собі провідні мотиви конфлікту твору. Вона кохає оспіваного у піснях звитяжного козака Саву Чалого, а ii хочуть віддати за нелюба Гната Голого. Як і Наталка Полтавка, так i Катерина про свою душевну драму повідомляє піснею, що виражає певне співчуття автора до героїні: «Чи я в лузі не калина була?.. Нащуо мене порубали $і$ гіллячки поламали?.. Нащуо мене засватали і світ мені зав'язали!» [Костомаров 1990: 182-183]. Для Катерини життя $з$ нелюбом гірше смерті, у пісні героїня виражає свій розпач: «Чи не було річеньки утопиться мені?» [Костомаров 1990: 183]. Кохання і коханий постають для Катерини вітальними цінностями. Своє горе Катерина підтверджує словами та гіркими сльозами: «Бідна моя головонька! (Плачет, ...закрывает лицуо руками). Не бути мені за ним - не бути мені ні за ким! Понесуть мене на грибовище: я умру з печалю!» [Костомаров 1990: 183-184]. Страх ослуху матері, сором відкритися їй у своєму коханні до Сави Чалого стали причиною іiі невтішного горя. Лише подрузі Насті наодинці вона відкриває свою душевну таємницю: «Ox, сестрище, душечко! Якби ти знала, як я люблю його!» [Костомаров 1990: 183]. Ці слова характеризують Катерину як щиру, пристрасну особистість, здатну на глибокі почуття. Автор акцентує на чутливості своєї героїні, їі щирості та вірності. Вона пишається своїм обранцем: «Ох, кращуого молоди̧я на світі нема. Про кого пісні співають? Кому молоді й cmapi дивуються?» [Костомаров 1990: 184]. Катерина ніжна, любляча дівчина, автор підкреслює це ремаркою та мовною партією героїні: «(кидается к нему на шею). Мій Саво, мій миленький!» [Костомаров 1990: 185].

М. Костомаров підкреслює також щирість, благородство і силу почуттів Сави до Катерини: «Хай Бог того покине, хто свою кохану покидає!» [Костомаров 1990: 186]. У цій фразі проглядається погляд на Катерину як абсолютну духовну цінність. До того ж лише Катерина здатна була заповнити той душевний вакуум, який утворився у душі Сави після зради батька та друзів. Це підкреслюють слова: «Один я зостався (Смотрит на нее с нежностью). 
О ні, я помилився, є щее у мене ти: іщее я не зусім сиротина!..» [Костомаров 1990: 186]. Катерину він ніжно називає: «Серденько, душенько моя!» [Костомаров 1990: 186]. Вона виявляє відданість своєму коханому, готова йти за ним на край світа, навіть померти 3 ним, співчуває Савиному горю, здатна розділити його гірку участь. Розчулений Сава дає оцінку самовідданості дівчини: «Ох, ти моя миленькая, добрая Катя! Вона на усе готова!» [Костомаров 1990: 186]. Образ Катерини М. Костомаров подає у динаміці. Спочатку вона боязка, а потім відкрито і сміливо виражає твердість на шляху захисту свого високого почуття до Сави, ставлячи його вище родинних стосунків: «Коли смерть, так обидвом вмісті! Я від тебе не одстану. Щоб мене грім убив, коли я хоч часиночку без тебе житиму! Мені без тебе ніщуо не дорого; коли ти справді задумав іти - я покину матір, таки піду за тобою!» [Костомаров 1990: 187]. Коханий для неї постає найбільшою цінністю у житті. I хоч Сава хвилюється за неї чи зможе вона перенести розлуку з рідними, нужду, голод, нестатки, які можуть їх спіткати в пошуках кращого життя, але Катерина налаштована рішуче, вона непохитна, категорична, дорівнює себе по силі та витривалості до чоловіка, докоряє коханому, що він міг засумніватися в ній: «Бач, який ти: ти так зможеш стерпіти, а я й не зможу! Я люблю тебе» [Костомаров 1990: 187]. Автор ставить жінку за силою духу на один рівень 3 чоловіком. Мовна партія Катерини характеризує іï як сильну вольову особистість: «Хоч $і$ к татарам, хоч на край світа! Я все-таки тебе не покину» [Костомаров 1990: 187]. Катерина своїм коханням, щирістю та відданістю здатна повернути Саві душевну рівновагу, це підкреслюється його мовною партією, сповненою захоплення, вдячності і молодецького завзяття: «Квіточка моя весняная! Ягідка моя червоная! Біля тебе ц̆ горе забудеш. Геть, каталажна думка! Я уп'ять Сава, той Сава, щуо був і преже. Нехай з мене знущиаться, нехай з мене глумують - $\epsilon$ у мене хто мене приголубить! Сердечко, рибонько! Катречко моя! (Целует ее со слезами). О, якби наші душки отак обвилися та заразом $і$ вилетіли з тіла!» [Костомаров 1990: 187]. Письменник акцентує на спорідненості душ Катерини і Сави, що є основою 
щастя. У той момент, коли мати Катерини побачила доньку у обіймах Сави, він виступає на захист честі своєї коханої, розповідаючи про велике почуття до неї і про чесні наміри: «Я на ї̈ нічого та худого не замишляв: я $\dddot{̈}$ любив... вона мене; нам обоїм одно без другого жити не любо. Що ж, кажуть добрі люде, щзо вірному коханню і Біг не противник! А я любив ї̈, і люблю, і вічно любитиму! Вона мене тож... За таке кохання нема гріха; ми не винні, щзо нам Біг серце дав» [Костомаров 1990: 188]. Образ Катерини постає як абсолютна та вітальна цінність, без якої життя неможливе, бо взаємна любов - основа природної гармонії, що панує в душі людини, найвища морально-етична цінність.

Щирість почуттів Катерини виявляється у іiі сміливому зізнанні матері у коханні до Сави: «Ох, матусю, люблю! (кидается к ногам матери). Матінко, ненечко! Прости ж мене! Я побоялась: так, сама не знала, щзо сказала сказала, та й сама не рада. 3 тої пори оџе мені така мука, щуо і хліб на думку не йде. Я люблю Саву, до віку вічного його любити буду! А Ігната Голого... як він мені на мисль прийдеться, так аж у грудях важко стане. Далебі, матінко, я тілько злякалася, а я люблю і любитиму одного Саву. Не розлучай мене з ним, матусю, бо і він мене любить!» [Костомаров 1990: 188]. Вона як і Наталка Полтавка знайшла у собі сміливість порушити звичай, щоб вибороти собі право на щастя з коханим. Позитивним у образі матері Катерини є те, що вона здатна зрозуміти почуття закоханих і підтримати їх у складній життєвій ситуації, теж знехтувавши звичай: «Хіба я тебе приневолювала, чи щзо? Ач! Сама собі жалю завдає! Коли вже так собі любитеся, то і Біг з вами. Я вам не розлучниця! От вам моє благословення!» [Костомаров 1990: 188-189]. Вона постає як мудра жінка, любляча мати, захищаючи прадавні синкретичні духовні цінності, якими були любов, щастя, хороший рід. Вона тонко відчуває душевну драму доньки i усіляко сприяє іiі благополуччю. У iï мові простежується і материнська ласка, i співчуття, і турбота, і співпереживання та вболівання за долю єдиної доньки. 3 надзвичайною ніжністю й Сава ставиться до Катерини, яка стала його дружиною. Його слова випромінюють любов і повагу до неї, до родинного тепла, створеного нею: «О, моє серденько! Одним одна моя радість на сім 
світі! ... Ніяк не налюбуюсь, дивлячись на тебе, не налилуюсь з тобою! Хоч до смерті милуватимуся - усе здаватиметься, щяо мало!» [Костомаров 1990: 211]. Дружина постає для нього вітальною цінністю: «Катю, Катю! Дай мені свою рученьку... Сонечко моє ясненькеє! Як мені біля тебе сидіти любо! Як мені на тебе дивитися мило! О моє сердечко!» [Костомаров 1990: 210]. Для Сави дружина здатна замінити увесь світ, бо лише 3 нею, він знаходить душевну гармонію, що є запорукою щастя. Він милується очима своєї дружини: « $A$, якi y тебе очі карі та ясні, дай поцілую!». Навіть у найскладніший період свого життя (конфлікту з батьком, козаками і Конецпольським) він залишається ніжним і люблячим чоловіком. Автор зображує Катерину як вірну, люблячу, самовіддану дружину, ніжну матір. Вона здатна на будь-які випробування аби бути поряд 3 коханим чоловіком. Коли Сава після розладу з Конецпольським говорить про можливі поневіряння, вона відповідає: «Хоч яке нещастя, я все терпітиму, аби з тобою нерозлучно бути» [Костомаров 1990: 211]. Навіть під страхом смерті Катерина відмовилась зрадити свого коханого і за вірність та любов заплатила своїм життям, вона $є$ втіленням кращих рис жінки, передбачених народним ідеалом, оспіваних у пісенному фольклорі.

У 1840-1841 рр. М. Костомаров зробив спробу «створити нащіональноісторичну геройчну трагедію, нею стала трагедія «Переяславська ніч». У ній йшлося «про подї початку національно-визвольної війни під проводом Б. Хмельницького - визволення Переяслава» [Смілянська1990: 13]. Ми цілком розділяємо думку В. Смілянської, що «новацією для української драми був образ сестри Лисенка й коханої старости - Марини... Це високо романтичний образ жінки, яка приносить у жертву заради визволення батьківщини свого коханого й сама бажає загинути разом з ним; коли ж ї брат $i$ коханий вбивають одне одного в двобої, вона йде в монастир» [Смілянська1990: 13-14]. М. Яценко стверджував: «В украйнській літературі це був перший образ жінки, яка бореться не за особисте щңастя, а за інтереси народу» [Яценко1979: 303]. У творі показано, як розгортається боротьба між особистими почуттями героїні і обов'язками громадянки. Брат Марини, покалічений до невпізнання ворогами, 
своїми розмовами збуджує іï патріотичні почуття, вселяє бажання помсти польській шляхті за знущання над народом. У образі Марини автор втілює велику і чисту любов сестри до брата, відданість сімейним традиціям. Марина як високодуховна особистість здатна на самовіддану любов, готова пожертвувати найдорожчим, щоб полегшити страждання брата: «Чи не змиють сльози Шрамів твойх. Губами висмокчу Весь гній із ран тобі. Ох, Боже! Немає ока! О, мій брате любий! Хоч би одно у мене можна вирвать I вставить в ямку! Я б була радніша» [Костомаров 1990: 249]. Вона переймається тривогами брата, виявляє твердість духу, хоче допомогти повстанцям і навіть привести їм старосту, хоч він для неї найдорожчий у світі: «Ох брате мій! Душа щуе в мене руська, I руське лихо дуже, дуже сериче Мені воруиить. Не зраджу вас. Того, котрого я люблю як душу, Як божий світ, як, братику, тебе, Я не спасу його!» [Костомаров 1990: 254]. Ці рядки підкреслюють відданість дівчини своїй батьківщині, своєму народу. Образ мужньої жінки-патріотки автор яскраво розкриває через іï поведінку та думки. Вона наділена рисами сильного вольового характеру. В. Івашків цілком правомірно відзначив: «Це принципово новий жіночий образ у всій украӥнській літературі того часу. На відміну від традищійних жіночих образів етнографічно-побутової драматургї 10-30-х років, Марина причетна передусім до інтересів загальнонародних: перед нею стоїть не питання за кого вийти заміж, а проблема, на чиїи стороні бути у боротьбі» [Івашків 1990: 54-55]. Марина, як українка-патріотка, не вірить у щирість слів старости, бо він поляк, шляхтич, тому вона вихоплює із його рук зброю і кидає іï у річку, прирікаючи, таким чином, свого коханого на явну загибель. У той же час вона так сильно його любить, що хоче померти разом 3 ним. Вона відрікається від Семена Герцика, свого нареченого, бо той, як виявилося, лише заради неї і воював з ворогом. Марина як справжня патріотка iз презирством кидає йому прямо у вічі слова: «О душа нікчемна!!! Так ти не за своїх братів недолю, Не за родину шаблю піднімаєи - За дівчину, паскудний бахур!»[Костомаров 1990: 263]. Вона закликає ставити найдорожче на олтар спасіння народу і говорить про свою непереборну любов відкрито і сміливо: 
«Знай же, I ви всі знайте, добрі люде. Правду Скажу вам перед смертю. Я Семена I не люблю, ніколи і не хочу Любить! От мій Францішек милий, любий, Із ним радніша вмерти. (Обнімає Францішка). Убийте нас укупі!» [Костомаров 1990: 263]. Своє життя, свою любов дівчина жертовно покладає на олтар свободи рідного народу. Автор акцентує на вольових, вітальних, національних цінностях особистості.

У заключній частині трагедії основна увага приділяється саме Марині, іiі брат Лисенко простив захоплених у полон старосту і його збройний загін не тільки для свого морального очищення, а й для того, щоб Марина знову була поставлена перед вибором: особисте чи загальнонародне. Коли староста діставши таким чином свободу, пропонує їй іти за ним, вона знову рішуче заявляє йому: «Я не піду з тобою, бо я руська» [Костомаров 1990: 270]. Для Марини обов'язок незрівнянно важливіший за особисті почуття. На думку В. Погребенника, «вольова переяславка - перша в украӥнській літературі патріотка, яка заради визволення рідного міста поступається особистими почуттями. Виконуючи свій громадянський обов'язок» [Погребенник 1992: 404405]. Марина - це сильна, вольова, пристрасна особистість, яка не йде ні на які компроміси, здатна на самопожертву, щира i волелюбна натура, яка виборює собі право свободи вибору. Це жінка, яка здатна захистити своє добре ім'я, свою честь, виявляючи своє шанування моралі та народних звичаїв: «Не насильно затягнув мене До себе староста. ... Я його невіста, Не полюбовниия; у мене досить Ще є душі на се. Чесним илюбом Ми б спарувались після свят» [Костомаров 1990: 253]. Марина дотримується морально-етичних норм рідного народу. Вона не здатна на відступництво від коханого, тому виявляє готовність загинути з ним разом, бо життя без нього втрачає для неї сенс: «Tепер Вже нам не жити на світі укупі... Як вірна заручена ляжу з ним В одній могилі» [Костомаров 1990: 253]. Кохання для неї постає як вітальна цінність. Марина тверезо i виважено оцінює суспільну ситуацію, засуджує загарбників за безчинства, виявляє високу громадянську та національну самосвідомість: «3a глуми, за наругу, за неволю, За кров, за сльози рідних ти прийшов Із ворогами 
розплатиться глумом, Наругою, неволею $i$ кров'ю, Прийшов защитить од посміху віру... Як грішників у пеклі дьяволи - Катують нас католики» [Костомаров 1990: 254]. Вона виявляє відданість народу, свідомо йде на самопожертву в ім’я перемоги над ненависними визискувачами. Автор акцентує на здатності дівчини критично оцінити масштаби горя та розрухи, що принесли ляхи на іiі рідну землю. Це вказує на когнітивно-інтелектуальну цінність дівчини, утверджує у правильності іiі вольового рішення: «Визволять від смерті Не буду я ляхів. Святую помсту Моїх братів не зраджу» [Костомаров 1990: 254]. Це підкреслює авторське бачення жіночого образу в руслі національних та соціальних цінностей. Введений у структуру трагедії хор прославляє дівчину за вірне кохання та патріотизм. Марина виявляє рішучість, вона не вагається у своєму громадянському виборі, але i не зрікається особистого почуття кохання, що осяває іï душу і серце. Автор вдало використав античний прийом для інохарактеристики героїні, щоб акцентувати на піi чеснотах, багатстві духовного світу. 3 вуст жінки-патріотки звучить усвідомлене нею звинувачення ворогів у підступності: «Хіба сльозам та клятьбам мусить вірить Од поляка вкраӥнецьь... Ви вмієте $i$ плакать, $i$ божитись,.. I раді стать навколішки, і Бога Призвати дурно - тільки б ворога Лукаво обманити ц̌ загубити... Чи не погибло ціле військо наме, А вслід за їм увесь народ наш бідний. Із тій години кожний поцілунок, Що лях вкраїнцеві дає, похожий На той, щзо Йуда Господу давав» [Костомаров 1990: 257-258]. Автор вводить у мову героїні зіставну паралель 3 біблійною легендою про підступність і зраду, що підкреслює розум, духовну зрілість героїні, яка розуміє, що не має права на життя любов між представниками двох народів, які ворогують. У творі акцентується як на національно-патріотичній, так і на когнітивно-інтелектуальній цінності жіночого образу.

Устами жіноцтва у «Переяславській ночі» говорить сама Україна, стомлена від поневолювачів. У пісні хору дівчат виражена позиція автора та основний задум твору: «Іспериу ви родиноньц̧і Слободу узверніть, Iсnершу чужестранців ви 3 родини проженіть. Тоді приходьте гратися Із нами на луку, 
I кожному дівчинонька Співанку заспіва, I кожного коханочка Квітками заквітча!» [Костомаров 1990: 248]. У прощальних словах Марини звучить віра у краще майбутнє вітчизни, звертаючись до брата вона говорить: «Щоб дивлячись на милу Україну, Слободную й щасливую, тобі I весело, і радісно було!» [Костомаров 1990: 270]. Дотримуючись народного звичаю, вона звертається до громади, надихаючи всіх вірою у краще прийдешнє: «Прощайте, люде добрі! Хай Господь Хранить родину нашу! Хай вона Цвіте собі, як маковая квітка! Я йду у монастир. Прощайте, добрі люде!» [Костомаров 1990: 270-271]. Образ Марини піднесено до рівня абсолютних духовних цінностей, як для брата, який називає за добру, милосердну, співчутливу душу іiі «мій анголь» [Костомаров 1990: 248], так і для старости, якого вона вірно кохає, він їй говорить «Ти анголь божий, з неба Злетівший» [Костомаров 1990: 258]. Образ Марини виписано в руслі народного розуміння ідеалу патріотки. У творі М. Костомарова гостро постає проблема національної приналежності. Вона подається як трагедія особистості у світі, де одна країна прагне поглинути іншу. У XIX ст. боротьба за свободу народу вимагала безкомпромісності, образ якої матеріалізувався митцем у образі Марини.

У романтично-піднесеному ключі подає образ жінки-патріотки М. Костомаров у трагедії «Переяславська ніч». Свою героїню він наділяє силою волі, духовною міццю. Крицевістю характеру вона не поступається чоловікам. Це особистість високодуховна, вільнолюбива, пристрасна, віддана своєму народу. Вперше в українській літературі середини XIX століття образ жінки постає як соціально та загальнонародно значима особистість, яка на вівтар народної свободи і щастя покладає найдорожче у житті: своє кохання, свого коханого, своє щастя і себе саму. Це велика жертва в ім’я перемоги над загарбниками. Почуття кохання як найбільша духовна цінність стає неможливим між представниками ворогуючих народів. Образ Марини постає в аспекті вічних, національних цінностей та сан критичних працінностей. Своїх героїнь М. Костомаров не ідеалізував, а відтворював ті риси ідеалу людини, які сформувалися внаслідок історичної діяльності українського народу, провідних 
ознак його ментальності, тому національна складова посідає чільне місце у авторській художній концепції жіночого образу та осмислення його в системі духовних цінностей.

\section{БІБЛІОГРАФІЯ}

Єфремов 1995 - Єфремов С. Історія українського письменства / С. Єфремов. - К. : Феміна, 1995. - 688 с.

Івашків 1990 - Івашків В. М. Українська романтична драма 30-80 років XIX ст. / В. М. Івашків - К. : Наукова думка, 1990. - 143 с.

Костомаров 1990 - Костомаров М. І. Твори: в 2 т. / М. I. Костомаров. Т. 1 : Поезії. Драми. Оповідання. - К. : Дніпро, 1990. - 538 с.

Лісовський 2005 - Лісовський А. М. Морфологія художнього твору i вивчення літератури в школі / А. М. Лісовський. - К. : Ленвіт, 2005. - 110 с.

Погребенник 1992 - Погребенник В.Ф. Микола Костомаров / В. Ф. Погребенник // Історія української літератури (Перші десятиріччя XIX століття): підручник / П. П. Хропко, О. Д. Гнідан, П. І. Орлик та ін. - К. : Либідь, 1992. - С.389-414.

Смілянська 1990 - Смілянська В. Л. Літературна творчість Миколи Костомарова / В. Л. Смілянська // Костомаров М. І. Твори: в 2 т. - Т. 1 : Поезії. Драми. Оповідання / М. І. Костомаров. - К. : Дніпро, 1990. - С. 5-37.

Яценко 1979 - Яценко М. Т. Питання реалізму і позитивний герой в українській літературно-естетичній думці першої половини XIX ст. / М. Т. Яценко. - К. : Наукова думка, 1979. - 335 с.

Яценко 2005 - Яценко М. Т. Микола Костомаров / М. Т. Яценко // Історія української літератури XIX століття: у 2 кн. - Кн. 1 : підручник / За ред. акад. М. Г. Жулинського. - К. : Либідь, 2005. - С. 318-354. 